\title{
THE STRATEGIC PROCESS OF DEVELOPING SOCIAL ASPECTS OF SUSTAINABILITY THROUGH THE VISION REFLECTION IN BUSINESS EDUCATION
}

\author{
Judita PETERLIN ${ }^{1}$, Vlado DIMOVSKI ${ }^{2}$, Manuela TVARONAVIČIENÉ ${ }^{*}$, \\ Barbara $\mathrm{GRAH}^{4}$, Arturas KAKLAUSKAS ${ }^{5}$ \\ 1,2,4Faculty of Economics, University of Ljubljana, Kardeljeva ploščad 17, 1000 Ljubljana, Slovenia \\ 3, 5 Vilnius Gediminas Technical University, Saulètekio al. 11, LT-10223 Vilnius, Lithuania
}

Received 06 June 2017; accepted 16 September 2017

\begin{abstract}
Empowering students in the higher education environment as a challenging pedagogical trend represents one of the key social aspects of sustainability. In this article we discuss the students' visions, their future development preferences and focus on the study and further achievements of the business students by analyzing the content of students' self-reflected dialogues. The traditional pedagogical approach is upgraded through the introduction of the conceptual model - The strategic process of developing social aspects of sustainability through business education. It emphasizes vision development, gender issues awareness, work-life balance, widening horizons and nurturing proactiveness, and aims to highlight the importance of attitude-related content besides knowledgerelated content. We advise the pedagogues to encourage personal development of their students in order to be able to identify different developmental types and individualize the study process, accordingly. The paper also provides practical implications for the incorporation into the syllabuses of the business school programs. Based on the analysis of up-to-date affective tutoring systems, authors' long-term experience and in order to determine most efficient versions of business education the Affective Tutoring System for Business Education (ARTSY) was developed.
\end{abstract}

Keywords: students' visions, social aspects, sustainability, reflection, empowerment, pedagogical approach.

JEL Classification: A22, I30, M10, M14.

\section{Introduction}

The capacity of higher education has doubled over the past twenty years. Those entering the system now and in the future will have very diverse learning needs. Higher education will need to develop and provide flexible opportunities for larger and more diverse student cohorts (Hunt, 2011; Dalati \& Al Hamwi, 2016; Raudeliūnienè, Stadnik, \& Kindarytė, 2016;

${ }^{\star}$ Corresponding author. E-mail: manuela.tvaronaviciene@vgtu.lt

This is an Open Access article distributed under the terms of the Creative Commons Attribution License (http://creativecommons. org/licenses/by/4.0/), which permits unrestricted use, distribution, and reproduction in any medium, provided the original author and source are credited. 
Fuschi \& Tvaronavičienė, 2016; Matetskaya, 2015; Oganisjana, Svirina, Surikova, GrīnbergaZālìte, \& Kozlovskis, 2017), to successfully enter the labor market. In the European Union, every year several millions of graduates of social sciences, business and laws, are entering the labor market, as approximately 4.8 million students graduated from tertiary education institutions in the European Union (28 countries) in 2012 and $34.4 \%$ graduates studied social sciences, business and law (Eurostat, 2015), whereof 54.3\% represented female students (Eurostat, 2015).

Empowering students in the higher education environment as a challenging pedagogical trend represents one of the key social aspects of sustainability. In this article we discuss the vision, development preferences and focus on further achievements of business students. Our research questions are twofold, namely: "What kind of personal visions do business students have?" and secondly, "How can pedagogues facilitate the vision development and implementation process in the higher education setting?" The traditional pedagogical approach has been upgraded through the use of proactive study exercises, where the emphasis was placed on the self-reflected dialogue. Qualitative method based on the narrative analysis was used to answer the research questions.

The task of educators is to facilitate the achievement of diverse visions in order to specify social aspects of sustainability (Epstein \& Roy, 2003; Volchik \& Maslyukova, 2017; Aleksejeva, 2016; Oganisjana \& Surikova, 2015; Tvaronavičienė \& Černevičiūtė, 2015; Branten \& Purju, 2015; Dobrovolskiene, Tvaronavičienė, \& Tamošiūnienè, 2017).

The paper presents the possibility of realization of such educational process by introducing the conceptual model - The strategic process of developing social aspects of sustainability through business education. The article also shows good practices of promoting students' creativity, achievements of equal opportunities between the sexes, as well as methods of reflection, building personality, learning about current challenges in local and global business environment, developing independent research skills (Carroll, Levy, \& Richmond, 2008) and linking theory with practice in order to upgrade the massive standardized lectures.

\section{Theoretical overview}

The strategic management process facilitates gap identification among current and desired sustainable future states (Hill \& Jones, 2007). Positive affects in terms of readiness for change and progress require vision to be effectively transferred (Kantabutra, 2010; Haque, TitiAmayah, \& Liu, 2016), meanwhile collective vision also advances service job satisfaction and efforts (Testa, 1999). Due to the fact that leaders are responsible for creating and communicating organizational vision (Nanus 1992, in Almog-Bareket, 2012), personal vision is a source for developing organizational vision (Crossan et al., 2008, in Yoeli \& Berkovich, 2010). An individual's enthusiasm, commitment and vision creating skills are required to implement change (Atkinson, 1999), consequently business students need to have vision crafting knowledge and skills required. Reflection of own vision in educational setting brings two types of benefits for students, firstly they make their personal visions explicit; and secondly, they practice vision crafting skills that business students will need in their professional career. 
Sustainable development programs reach their potential if they are designed as a leadership identity-building environment. They need to improve individual's leadership perception, understanding of the setting in which one is active and define leadership as responsible behavior in the society (Petriglieri, 2012).

DeRue and Wellman (2009) found that the main development tools of leaders are their gained experiences and feedback that was received in the dialogue with the stakeholders. Experience is not an automatic learning, and business schools need to help in maintaining the personal responsibility of individuals for their own development and raising motivation and ability to learn from experience (DeRue \& Ashford, 2010). McCall (2010) claims that experiences are at the center of leadership development. Developing sustainable leadership does not neglect the development at an early stage. Most of the research is focused on the development of leadership development techniques in adulthood (Murphy \& Johnson, 2011).

Term vision derives from Latin and stands for "to see" (Almog-Bareket, 2012). Vision shows direction, articulates a sense of purpose, clarifies a set of ideals, as well as defines uniqueness (Berson, Shamir, Avolio, \& Popper, 2001). Vision statements should be ambitious, yet achievable (Hill \& Jones, 2007) in order to motivate people and stimulate change. Vision creation process has several steps (Levin 2000): becoming informed; visiting the future and record it; creating the story and vision deployment. With no vision, we only react to outer stimulus and it cannot be successful on the long run (Miles, Snow, Meyer, \& Coleman, 1978). Strategic vision is build of two parts (Boal \& Hooijberg, 2000): cognitive, focusing on outputs for its accomplishment and affective, drawing on individual's beliefs and values that influence inspiration. Key characteristics of vision are clarity, abstractness, brevity, future orientation, challenge, stability, and desirability (Kantabutra, 2010; Haque et al., 2016). According to Levin (2000), good vision is bold, and passionate, as well as full of experience and knowledge.

Dialogical pedagogy (Collinson, 2005) can represent improvement of sustainable leadership development (Grooms \& Reid-Martinez, 2011; Gurr, 2007; Hargreaves, 2007; Peterlin, Dimovski, Uhan, \& Penger, 2015). Students are invited to interact with co-students through appreciative inquiry methodology (Barrett \& Fry, 2008) and gather data in the management field with the contemporary local managers in their surroundings which offers them firsthand sustainable experience (Avery \& Bergsteiner, 2011) of management practice supported with textbook and lectures. Berkovich (2014) suggests the following components of dialogical pedagogy: self-exposure, open mindedness, empathy, care, respect, critical thinking, contact, and mutuality. Ungaretti, Thompson, Miller, and Peterson (2015) claim that problem-based learning is a needed approach to management education focused on skills development, therefore we designed our home works where students can actively practice managerial skills while gathering data and answering questions.

We can approach developing reflexivity through reflection (Boyce, Zaccaro, \& Wisecarver Zazanis, 2010) in several phases (Hibbert, 2012): (1) Prepare for reflection and make space for it in the curriculum; (2) Use critical dialogue to engage with diversity and foreground power; (3) Unsettle comfortable viewpoints/familiar concepts; and (4) Develop new perspectives through ideological exploration and "sociological imagination".

Students take charge of their interest and can choose topics from the textbook that are most interesting to them. They can also help themselves with modern IT technology. 
Zemlickienè, Mačiulis, and Tvaronavičienè (2017) defined the importance of factors in the commercial potential of technologies with the help of expert research. The lecturers and assistants are available for additional help and guidance to the students. Home works also enable those students who lack in knowledge to prepare themselves with guided assignments, whereas those students who wish to learn and know more can choose more demanding home works among several options offered.

\section{Method}

To be able to empower the students within the pedagogical process, the teacher should know the students well - their ambitions, development preferences and focus of their further labor achievements that would allow adapting the standardized teaching program to different student preferences. As such, the qualitative approach (Bansal \& Corley, 2012; Boeije, 2010; Eriksson \& Kovalainen, 2008) to collect the content rich, self-reflective dialogues was chosen as the most appropriate method for collecting the data. With that in mind, students were given an optional assignment to think about, reflect and record their personal visions by answering the following open question: "Personal vision: imagine yourself in 20 years. Record: Who are you? What do you do for a living? Are you a professional, working in local or international environment? Write down what you do, where you live and what are the values that guide you in achieving your goals, when thinking about your life in 20 years."

The questionnaire was distributed among the students attending the Foundations of management and organization course within the $1^{\text {st }}$ year of their undergraduate study at the at the Professional Degree Programme - Business Administration, the Faculty of Economics University of Ljubljana, Slovenia, and in total in the first phase of research 187 students' responses were collected. Whereas in the second phase of research, focused on further enlightenment of the second research question, additional 19 students answered open-ended questionnaires in order to gain further insight into the phenomena and triangulate the findings. In both research phases the unit of analysis is student.

Joint content analysis of the provided personal visions was selected as the most appropriate method to analyze the data, in order to qualify qualitative data collected, by understanding its context. The developed narratives embed a socio-cultural context in which the narrator lives, so the purpose of the narrative analysis is to make sense of the narrative and of the socio-cultural context through analyzing qualitative data, with the aim to identify the theoretical formulations and concepts, as part of the interpretation. The content analysis allows recognizing parts of the whole, connected to certain phenomena and its attributes (Penger, 2006). In order to provide an interpretation-free analysis we also ran a Word Frequency Query in NVivo software.

Based on collected inputs and first screening of the data, the following classifications were prepared. Student visions of their career paths were categorized in three main areas; (1) entrepreneur, (2) manager, and (3) specialist. Within the (1) entrepreneur vision, students saw themselves as different types of entrepreneurs: (1.1) internal entrepreneurs in term of working for innovative companies and fulfilling their entrepreneurial drives, (1.2) start-up entrepreneurs, in terms of establishing own start-up, high-tech companies, (1.3) entrepreneurs of classical company (bakery, accounting, and similar), (1.4) entrepreneurs active in arts, sports 
or charitable organizations, (1.5) entrepreneurs as franchisers of international companies, or as (1.6) entrepreneurs in terms of inheriting their family/parents organizations. In addition, (2) manager classification was further divided into three categories: (2.1) manager of a Slovenian subsidiary of an international company, (2.2) manager of/in an international company, and (2.3) manager of/in a smaller company. On the other hand, specialist/expert in specific area was not further classified and encompassed the positions within the accounting, clerk, tax authority, banking and other similar fields.

Related to the place of work and living, the following classification was set: (1) planned moving abroad, (2) living in Slovenia, actively involved with international environment (as for example business partners, business trips), (3) possibility to move, and (4) not moving abroad. In addition, also their proactiveness during the study was analyzed, and classified as (1) being proactive, searching for opportunities, (2) collecting practical experiences (e.g. student work, but not necessarily directly related to their vision implementation), (3) being aware they need to be proactive, but no concrete activity was reported, and (4) there was no information regarding their proactiveness provided. Nevertheless, also the information whether students foreseen their families and family lives, as well as work-life balance was observed. In case a student mentioned more career paths or options, it was recorded more times. The qualitative data were quantified, and in case of different opinions on the context, the discussion among the co-authors was made to reach the final consensus. Meanwhile, in the second research phase the in-depth data is presented in the form of proof citations.

\section{Findings}

Besides providing students with content-related knowledge, pedagogues should also encourage students to develop their personal visions as developed conceptual model (Figure 1) highlights. Conceptual model was inductively build based on collected and analyzed data. We identified 5 stages which we elaborate upon the results gained in research phase 1 and phase 2 .

Stage 1 requires pedagogical staff to encourage students to develop their personal visions. The research findings show that students have a diverse and very wide range of visions, as presented in Table 1. In general, students' visions can be divided into three main groups: entrepreneurs, managers and specialists. Of all representatives who participated in a study, $53.1 \%$ of students see themselves as entrepreneurs, $25.6 \%$ as managers and $21.3 \%$ as specialists. Due to different prerequisites focuses and interests needed, it represents a challenge for a teacher to involve them all into the content due to the standardized teaching process within the business studies, as it prevents customizing and upgrading of targeted individual competences.

Stage 2 requires pedagogical staff to build gender differences awareness. The research further shows, that despite there are more female students compared to their male counterparts in the higher education environment (Eurostat, 2015), as also representative in the first research phase of the study (187 students participated in this study, whereof $39 \%$ male and $61 \%$ females), female students rarely envision themselves as occupying high-ranking jobs. 


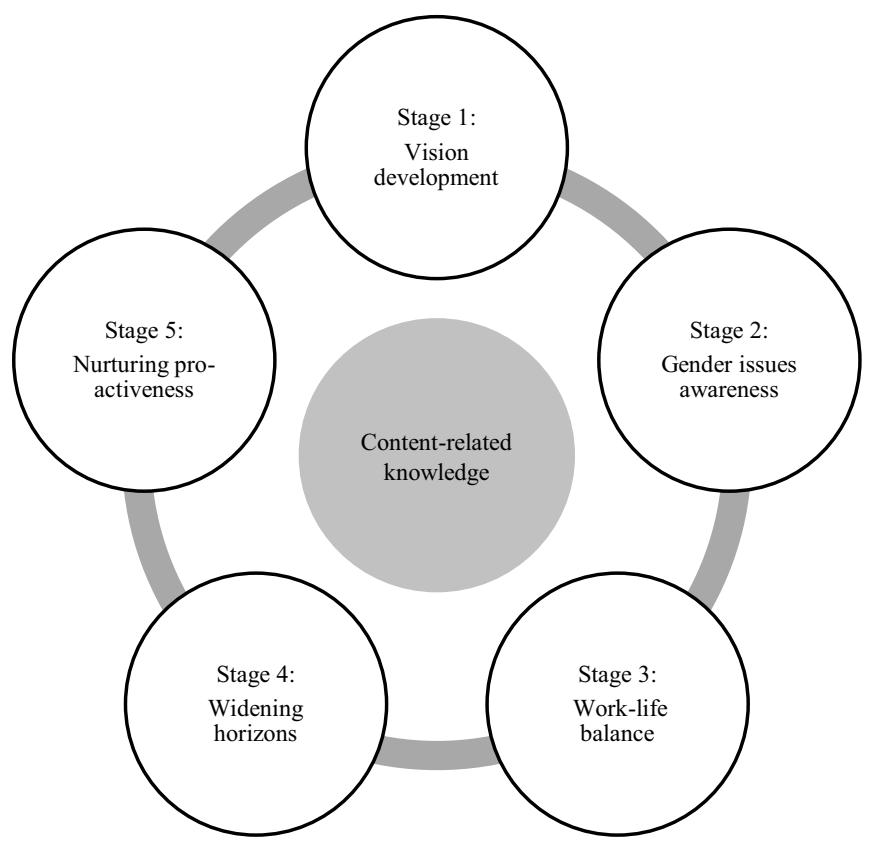

Figure 1. The strategic process of developing social aspects of sustainability through business education

The reason might be also that female students express their visions in terms of care and creation of a supportive environment and family; meanwhile their male counterparts do so less often as reveled in research phase 1 and phase 2 . Of total students, $54 \%$ envisaged their family. However, there is a larger difference between genders; $65.8 \%$ of total female representatives saw themselves as having a family, compared to $35.6 \%$ of male students representatives, who envisaged their family.

Proof quotes of business students' visions:

Female student A: "When I set myself a goal, I strive to achieve it. Some time ago I was a very fragile person and I quickly broke, and now I become very strong and this also encourages me to better achieve my goals. In the future the main motivation for me will be my family, for which I will take care of and support."

Female student B: "I imagine myself in 20 years as a graduated economist who lives and works in London. I would work in a travel agency as director. I would carry out the work and had good relationship with all the employees. After each progress of the agency I would organize a party in order to celebrate well performed job. Before I would marry and build a family, I would travel, enjoy, meet new friends, try out different foods and learn at least one new language. I see myself married with 3 children. Every weekend we would travel somewhere where there is no modern technology." 
Table 1 . Variety of visions in percentage per stages

\begin{tabular}{|c|c|c|c|}
\hline $\begin{array}{l}\text { Stage 1: Vision development, Stage 2: Gender } \\
\text { issues awareness }\end{array}$ & Females \% & Males \% & Together $\%$ \\
\hline Entrepreneur - internal & 0.77 & 1.23 & 0.95 \\
\hline Entrepreneur - start-up & 1.54 & 8.64 & 4.27 \\
\hline Entrepreneur - classical company & 35.38 & 39.51 & 36.97 \\
\hline Entrepreneur - art, sport, charitable organization & 5.38 & 6.17 & 5.69 \\
\hline Entrepreneur - franchisee & 1.54 & 0.00 & 0.95 \\
\hline Entrepreneur - family organization & 3.85 & 4.94 & 4.27 \\
\hline $\begin{array}{l}\text { Manager - Slovenian subsidiary of an international } \\
\text { company }\end{array}$ & 5.38 & 0.00 & 3.32 \\
\hline Manager - international company & 10.77 & 17.28 & 13.27 \\
\hline Manager - smaller company & 9.23 & 8.64 & 9.00 \\
\hline Specialist/expert in specific area & 26.15 & 13.58 & 21.33 \\
\hline Total & 100.00 & 100.00 & 100.00 \\
\hline Stage 2: Gender issues awareness & Females \% & Males \% & Together $\%$ \\
\hline Family & 65.79 & 35.62 & 54.01 \\
\hline Family not mentioned & 34.21 & 64.38 & 45.99 \\
\hline Total & 100.00 & 100.00 & 100.00 \\
\hline Stage 3: Work-life balance & Females \% & Males \% & Together $\%$ \\
\hline Work-life balance mentioned & 23.68 & 30.14 & 26.20 \\
\hline Work-life balance not mentioned & 76.32 & 69.86 & 73.80 \\
\hline Total & 100.00 & 100.00 & 100.00 \\
\hline Stage 4: Widening horizons: Moving abroad & Females \% & Males \% & Together $\%$ \\
\hline Yes, planned & 22.22 & 32.43 & 26.18 \\
\hline $\begin{array}{l}\text { Living in Slovenia, actively involved with } \\
\text { international environment }\end{array}$ & 34.19 & 36.49 & 35.08 \\
\hline Possibility to move & 14.53 & 10.81 & 13.09 \\
\hline Not moving abroad & 29.06 & 20.27 & 25.65 \\
\hline Total & 100.00 & 100.00 & 100.00 \\
\hline Stage 5: Proactiveness during study & Females \% & Males \% & Together $\%$ \\
\hline Being proactive, searching for opportunities & 7.02 & 9.46 & 7.98 \\
\hline Collecting practical experiences & 24.56 & 29.73 & 26.60 \\
\hline Awareness, no actual activity reported & 21.05 & 13.51 & 18.09 \\
\hline No information & 47.37 & 47.30 & 47.34 \\
\hline Total & 100.00 & 100.00 & 100.00 \\
\hline
\end{tabular}


Female student C: "At the beginning, I would do all office operations, as at newly established company there would be no additional workers. Later, when the company grows and extends, I would employ other workers and become Head of marketing. The company would be successful in international area, having subsidiaries in developed countries as Germany..."

Stage 3 requires the attention to be given on work-life balance. Male participants emphasized more often the work-life balance $(23.7 \%$ of all female and $30.1 \%$ of all male participants, $26.2 \%$ in average).

Proof quotes of business students' visions:

Female student D: "In addition to my career I imagine myself settled with my family. My values will change by then and most important for me will be family and health. I wish that I will have in my daily routine enough free time despite I believe that free time spent with your loved ones is as important as success in the career. I think that I will never move abroad because it is hard for me to adjust to the new environment and I am very attached to family and friends. Even if I would receive good job offers abroad this would would be a pretty tough decision for me. I imagine my life in Ljubljana, or some place in the vicinity of Ljubljana. I want to be surrounded by sensible people and my current friends."

Female student E: "I see myself in 20 years as a woman in late 30-ies who lives happily with her family. I am a mother of 3 children and a good wife to my husband. We live in a village in a nice house by which fruit trees grow. In addition to caring for the family and household, I run a family business. We are engaged in domestic fruit, vegetables, natural fruit drinks and jams production and selling. In the cultivation and processing of fruits and vegetables my children also help, because this is the best school of life".

Male student A: "My most important values are family, home and health. I wish to have my family as close as possible to me, because family is the one that will help me build a career and independent life. The biggest motivation for me is my mother, since she is leading a successful company and is showing me the way which I want to walk in the next 20 years and will have to develop it on my own, of course. As my other value is also my family where I want to relax and simplify my life, and not just studying about the company. In doing so, I must not forget about my health of which I need to take care. I will regularly take care of my psycho-physical condition, and I'll be ready for new challenges. Even in business, it is important to stay in good shape, that you are not overcame by stress and other factors that greatly affect our well-being."

Male student B: "Practicing sports is important in my life, as I can relax totally. Besides achieving better general well-being by practicing sport, I would also remain in a good condition, as I will be most probably sitting most of the working time. This is also one of the most important things we can do for our health and improved immune system."

Stage 4 requires the attention to be given to widening horizons. Nevertheless, it appears that business students wish to work in the global business environment after completing their studies. Concretely, in average, only $25.7 \%$ of participating students do not want to move $-29.1 \%$ females and $20.3 \%$ males, meanwhile $26.2 \%$ representatives plan to move abroad (22.2\% females and 32.4\% males). On the other hand, $35.1 \%$ students plans to live in the local community, but be actively involved within an international environment (business 
trips, foreign partners, and similar - 34.2\% of all females representatives and 36.5 male representatives. Nevertheless, $13.1 \%$ of participating students mentioned a possibility to move (14.5 of all female representatives and 10.8 of all male representatives).

Proof quotes of business students' visions:

Male student C: "I have very high goals for my life in 20 years to which I would like to come as close as possible. I hope to live in a country, such as Australia, Switzerland, South Korea, the USA, New Zealand ... I hope by then that I will finally move into one of these countries, as there you have in comparison to Slovenia much greater chance of success and promotion. My ideal profession would be to work in the higher management of a successful company or I would have my own business. I would like to lead the company, which is engaged in the distribution of new products that are not present in a particular country, yet. My company would operate in an international environment. By this I mean that I would have a business in at least two countries (eg. USA and Germany)."

Female student F: "In 20 years I see myself as the director of an international company, therefore I would like to work in an international environment. I think I would be successful in this area because languages do not represent a problem for me and I am also communicative and committed to work. As director I would travel around the world to various fairs and learn about other companies and cultures of different countries. If it would be possible I would live somewhere abroad, and there thrive and be successful there."

Female student G: "I see my life in 20 years as independent, on my own, in my house and with my own family. I wish to create this on my own, with my own effort and own savings that I set aside already today. I have not chosen the exact location, yet. If the economic situation in Slovenia does not improve in the short period of time it is my intention to leave the country and to find a job, start my family and home, abroad. My dream country is namely Spain, because I very much like the state itself, and I love the Spanish language so that I can imagine myself there. If, however, I remain in Slovenia, I would probably move to the suburbs of Ljubljana or Domzale. I would live somewhere on the edge of town, surrounded by nature..."

Stage 5 focuses on nurturing the pro-activeness. The results further show, that $8 \%$ of students have been proactive during their studies, and are searching for opportunities, actively. 26.6\% of all representatives collected practical experiences (not necessarily related to their vision), and additional $18.1 \%$ is aware that they need to be proactive, yet they report nothing about actual actions taken. $47.3 \%$ of participating students reports nothing on proactiveness during their study (see Table 1).

In order to gain further insight how pedagogues could help their students in becoming more proactive and implementing their visions we provide proof quotations of students' reflections. Students expressed that professors could help them in vision realization in the following ways:

"Professors need to love the field they are teaching so that they can attract students, meanwhile we need to have the desire for learning. If there is no desire, professor can do nothing." (Female student $\mathrm{H}$ )

“Directing, showing different possibilities." (Female student I) 
"I believe it is great to expose us and give us options to collaborate." (Female student J) "More interactive learning, discussions during lectures on current topics that are happening in the world." (Male student $\mathrm{D}$ )

"Maybe it would be useful to lecture in a way to build foundation for independent study and give us the contacts of persons from practice on which we can turn to if we want work with someone concretely." (Male student E)

"Life-stories of good and bad experiences - learning from other people's mistakes" (Male student F)

"More practical examples." (Male student G)

"More collaboration on the part of students, sharing of students' experiences." (Male student H)

"Giving up to date content and practical examples." (Male student I)

"Providing more personal experiences, knowledge, directions and advices." (Male student J)

"Presenting wrong and failed projects, decisions, wider perspective why it happened." (Male student $\mathrm{K}$ )

"Implement brainstorming of similar thinking students and help them to realize their goals. As much practice as possible." (Male student $\mathrm{L}$ )

Overall, the research findings of the used pedagogical approach show: (1) Students have a diverse and wide range of visions, which represents a challenge for the teacher due to the standardization of the teaching process, preventing customization and upgrade of targeted individual competencies; (2) Despite the increase in the number of female representatives in the higher education environment, they rarely see themselves as occupying more responsible business roles in the international environment compared to male representatives; Research has shown that female students express their visions in terms of care and creation of a supportive environment and family more often than male representatives; (3) Majority of students expressed their wish to be integrated into the international business environment.; (4) Among different professional paths it seems that entrepreneurship is the most popular in terms of establishing their own classical company; (5) Student express the need for professors to demonstrate personal approach to managing, that is sharing of their practical experiences, networks and advices in overcoming obstacles in entering professional community.

\section{Affective tutoring system for business education}

The European Commission (2011) stresses a strong need for flexible, innovative learning approaches and delivery methods. As the European Commission (2011) reports, one key way to achieve this is to exploit the transformational benefits of ICTs and other new technologies, in line with the EU Digital Agenda, to enrich teaching, improve learning experiences and support personalised learning. Member States and higher education institutions that conform to the European Commission (2011) should better exploit the potential of ICTs to enable more effective and personalised learning experiences, and teaching and research methods (e.g., e-Learning and blended learning) and increase the use of virtual learning platforms. 
Conforming to European Commission (2013) involves new trends in digital education, and the emergence of massive open online courses should be an incentive for higher education institutions to rethink their cost structures and possibly also their missions and engage in worldwide partnerships to increase the quality of content and of the learning experience through blended learning.

Blended instruction has been more effective in recent experimental and quasi-experimental studies contrasting blends of online and face-to-face instruction with conventional face-to-face classes. These have provided a rationale for the effort required to design and implement blended approaches. The online and classroom conditions in many of these studies showing an advantage for blended learning differed in terms of time spent, curriculum and pedagogy. At the same time, one should note that online learning is much more conducive to the expansion of learning time than is face-to-face instruction (U.S. Dept. of Education, 2010). The main advantage of blended learning is the opportunity for instructors to make use of the features unique to each delivery environment that optimizes learning (Clark, 2012).

Blended learning allows teachers to improve efficiency in the classroom. Blended learning is able to personalize education. When teachers stand in front of a sea of desks and educate students about a new concept, kids of varying academic skill levels are not able to take extra time or work ahead as they may need. Blended learning allows students to work at their own pace, making sure they fully understand new concepts before moving on. Rather than playing to the lowest common denominator - as they would in a traditional classroom teachers can now streamline their instruction to help all students reach their full potential (DreamBox, 2013).

Software used with blended learning programs is able to collect student data that measures academic progress. In this way, teachers can clearly see the areas in which each individual student is excelling, and where he or she may need a little more guidance, and act accordingly. It is one of the most rational possibilities for massive personalized education (DreamBox, 2013).

As per the opinion of Chen (2014), the ongoing boom in online learning opportunities has been a great benefit for many gifted youth (different in their abilities, interests, and needs), because the offerings can cater to a student's ability rather than age. Gifted students may get bored and cranky when they easily grasp lessons ahead of the group in a standard classroom. As a result, gifted students and their parents often must cobble together their own individual education plan from various sources to obtain a deeper, more advanced intellectual dive than what standard school systems can provide. Therefore the Stanford Online High School's philosophy is to place students into courses by their ability, not age or grade level (Chen, 2014).

According to Daly (2009), Intelligent Tutoring Systems are blended learning solutions, not seeking to replace the teacher but to aid the teacher both in and out of the classroom and function as an aid in the delivery of the curriculum.

Development of affective tutoring systems has started recently. Descriptions of several of them appear below. Conforming to Amelsvoort, Joosten, Krahmer, and Postma (2013), systems that consider emotions are called Affective Tutoring Systems. The concept of ATS involves both collecting the emotion, which has an affective time from seconds to three 
minutes, and collecting the mood, which may last from minutes to days or weeks (Moga, Antonya, \& Boboc, 2014). Currently numerous affective tutoring systems apply multi-modal approaches for identifying learner emotions.

Recently, there is a tendency to move affective computing technologies into intelligent tutoring systems (ITS) (Hernandez, Arroyo-Figueroa, \& Sucar, 2007; Hernandez, Sucar, \& Arroyo-Figueroa, 2008; Kaklauskas, 2015). This is one of the major directions for improving global ITS. Affective computing systems, which can recognize, interpret, process and simulate human affects, are under development worldwide for including this very purpose. These are starting to serve as foundations for developing affective tutoring systems (ATS). ATS aim to evaluate the body language and physiological parameters of learners by making use of biometric and intelligent technologies and react better to the emotional states of learners on such bases. This is no ordinary process with a singular meaning, because students feel various emotions at the same time.

Therefore, for example, while, ATS analyse a student's body language and physiological parameters and establishes whether a student is bored or absent-minded, an effective interpretation of the emotional state requires a multi-modal, biometric perspective (as tone, facial expression, eye pupils, and other aspects are under analysis).

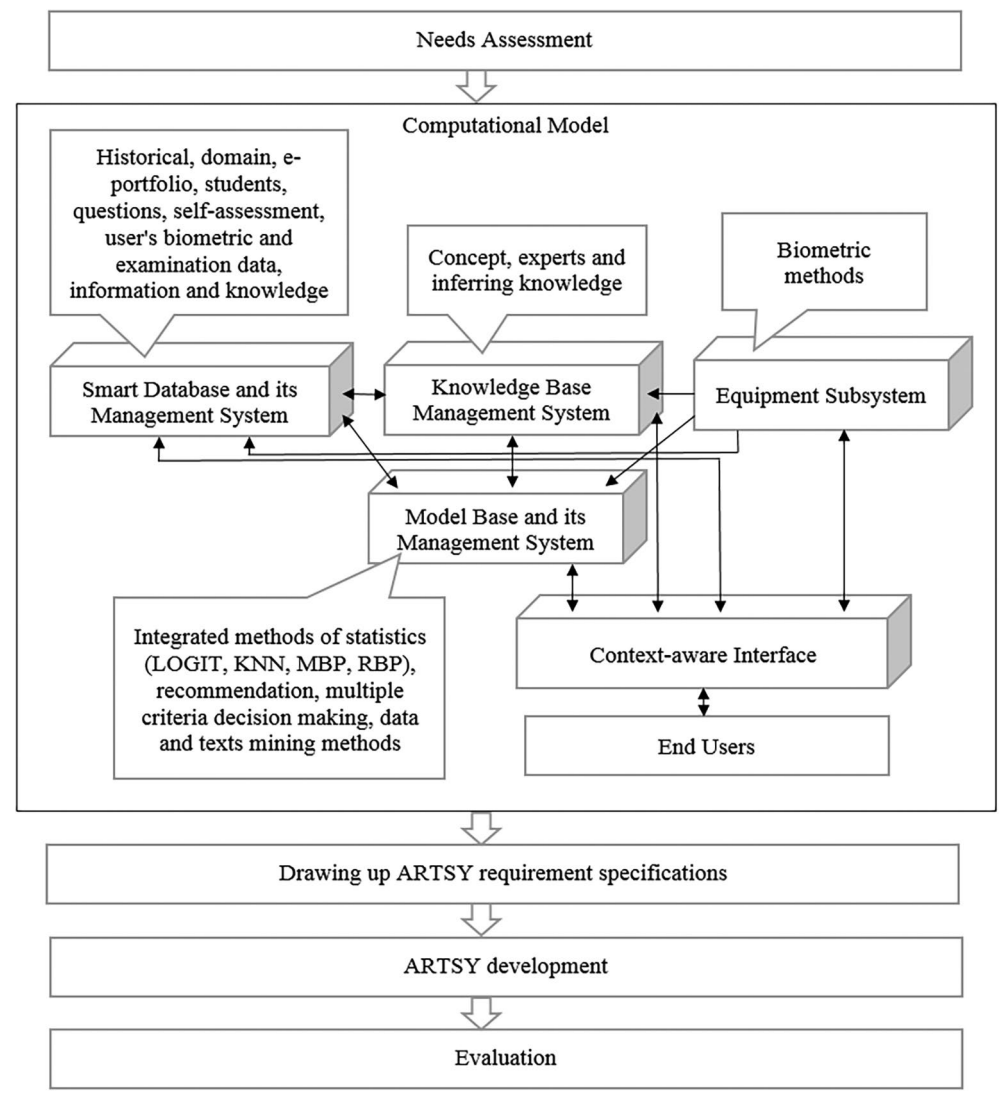

Figure 2. Conceptual model of an affective tutoring system 
Researchers worldwide are developing affective tutoring systems that employ only one biometric or affective method. However, hybrid affective tutoring systems (Hogo, 2010; Klašnja-Milićević, Vesin, Ivanović, \& Budimac, 2011; Kaklauskas, 2015; Kaklauskas et al., 2010, 2011, 2013, 2015) are also under development aiming to overcome the limitations of unimodal systems. The hybrid method combines two or more biometric or affective methods that model the learners in an integrated way depending on the data, information and knowledge. Hybrid methods exploit the worthy features of diverse biometric or affective methods by spreading them over affective tutoring systems tasks that they can reasonably model. A hybrid affective tutoring system has the advantage of covering a greater number of intelligent systems within its architecture that permit additional elasticity in learner modelling.

Based on the analysis of above research, authors' long-term experience and in order to determine most efficient versions of business education the Affective Tutoring System for Business Education (ARTSY) consisting of a Smart Database and its management system, Model-base Base and its management system, Knowledge base management system, Equipment subsystem and Context-aware interface was developed (see Figure 2).

\section{Discussion and conclusion}

Higher education institutions hold a vast responsibility in transferring and developing social aspects of their everyday pedagogical approaches and therefore one needs to be aware of understanding the impact of the content evaluation by the students. Our aim is to help students in understanding strategic management process, more specifically, vision development and implementation process and at the same time provide a setting for their personal development in terms of grasping their values and wishes for the future. As showcased in the educational settings of leader development, personal vision statements teaching method also contributes to students' personal growth (Hartman, Allen, \& Miguel, 2015). Longitudinal study of Holtschlag and Masuda (2011) demonstrates the articulation of challenging and specific student's career visions effect positively on their later job satisfaction and lowers their turnover intentions.

"Global business environments and the internationalization of education have positioned management education as a global phenomenon. [...] This presents challenges as to how we can best make our programs, pedagogic efforts, and learning environments responsive to multiple cultures given that they are largely imbued with Western or Anglo-American values tied to business schools. We argue that these matters bring into focus the impact of culture on individual beliefs about knowledge and learning behaviors." (Hardy \& Tolhurst, 2014, p. 265).

Vision creation is a part of strategic management that is incorporated in the management education as a course material and skill development. We discuss the importance of intrinsic motivation identification and creative exercise that can stimulate inner research of the students. Our study demonstrates positive effects of the vision creation exercise and several different inspirations and role models for the students' future paths that we elaborate upon and provide future recommendations for pedagogues. As its main steps it emphasizes vision development, gender issues awareness, work-life balance, widening horizons and nurturing proactiveness, aiming to highlight the importance of attitude-related content besides knowledge-related content. 
In addition, word frequency results indicate that students value "work" the most. Students mainly envision themselves working in a "company". Strongly present in their expressions are also "family", "people”, "knowledge", "business", and "goals". We can support our results' interpretation by identifying the most commonly emerging students' themes, as also terms as "international" and "abroad", "family" and "children", "director" or "accounting", appear often. Yet, it is important to note that it was an open-ended question, and students were able to use their words to describe their visions, therefore for example, they used different terms e.g. manager, leader, director, and consequently, the word query did not reveal specific theme as most often used. Similar goes for entrepreneurship, as more often naming themselves in the future as entrepreneurs, they explained their visions in terms of having and running own company or used other similar terms.

Our findings show that students welcome homeworks that support their professional and personal development. They have responded well to the vision writing homework and provided rich qualitative data that helps pedagogues improve the teaching process. Next year the course will implement a module where this year students will present the implementation of tactical and operational goals to achieve their stated vision and serve as a role model for the current generation of first year students. Empowerment through being aware that the future starts today is a powerful tool that students understood through the exercise.

\section{Theoretical implications}

Vision creation and implementation offer business educators an avenue to gain internal perspective of the concepts taught. Research supports that vision creation represents flexible opportunities for larger and more diverse student cohorts (Hunt, 2011). Our research shows that business students have diversified personal visions for themselves. They see themselves as future entrepreneurs, managers or specialists. In the conceptual model we have identified the five pillars of the leadership identity-building environment in the business education environment through which the pedagogues can facilitate the vision development and implementation process, that are vision development, gender issues awareness, work-life balance, widening horizons and nurturing proactiveness by highlighting the need to improve students and pedagogues perception of personal and professional development.

Due to the fact that most research is focused on the development of leadership development techniques in adulthood (Murphy \& Johnson, 2011) our paper offers important value added in terms of providing a conceptual model for developing social aspects of sustainability through the vision reflection in business education. By identifying the gap in the offered theoretical leadership development frameworks for younger generations we have, therefore, provided based on our research the conceptual model that is suitable for the specific developmental environment of business community, especially business students and pedagogues needs. We state that vision creation and implementation is a key element in sustainable leadership development that needs to start in the educational setting. Our research also adds knowledge to the sustainability field as business students' visions encompass economic, ecological and social dimensions. 


\section{Practical implications}

Action learning for students represents the main developmental value in terms of practical implications for further students' personal and professional development. In addition to provide the students with content related knowledge also attitude-related knowledge in terms of self-inspection is offered. We state that attitude-related content besides knowledgerelated content needs to be incorporated into the syllabuses of the business school programs in order to improve the pedagogical process based on the researched guidelines and identified 5 stages. Vision creation and implementation has several social aspects. It influences the definition of the student's role in the wider society, commitment to achieve the set goals and motivate themselves. Our paper also raises awareness among business community on future employees' characteristics and attitudes. Students gained actual experiences of the strategic management process through vision creating steps and applied it to their own personal setting, by analyzing their present environment and foreseeing their future wishes. The authors experienced that this made students gain responsibility for their actions and see the connections between their today's thinking and actions and their consequences, therefore making them more proactive even in the chosen exercise as well as their lives.

In addition, important practical implications are identified for business schools. It was researched that sustainable leadership development needs to be set at an earlier stage, and nurture different student attitudes, not to lose their underdeveloped potential by offering single pedagogical approach. Pedagogues need to find the time to get to know their students' needs and their potentials and we provide one of the approaches to do so based on developing reflexivity through reflection. Our conceptual model can be used as guiding principles. Results clearly state that students expect from pedagogues a proactive approach towards personal vision development and implementation.

\section{Limitations}

There are some research limitations in our study. Limitations of the study are connected to time and size. First, we only handed out personal reflection questionnaires to students at the Faculty of Economics, University of Ljubljana. Second, our research results are limited to Slovenia, however this suggests the possibilities for further research to be expanded internationally based on existing experiences and to be deepened and broadened. Nevertheless, when preparing the NVivo analysis, some meaning might be lost also during the translation process, as students wrote their visions in Slovene language.

\section{References:}

Aleksejeva, L. (2016). Country's competitiveness and sustainability: higher education impact. Journal of Security and Sustainability Issues, 5(3), 355-363. https://doi.org/10.9770/jssi.2015.5.3(4)

Almog-Bareket, G. (2012). Visionary leadership in business schools: an institutional framework. Journal of management Development, 31(4), 431-441. https://doi.org/10.1108/02621711211219086

Amelsvoort, M., Joosten, B., Krahmer, E., \& Postma, E. (2013). Using non-verbal cues to (automatically) assess children's performance difficulties with arithmetic problems. Computers in Human Behavior, 29(3), 654-664. https://doi.org/10.1016/j.chb.2012.10.016 
Atkinson, S. (1999). Reflections: Personal development for managers-getting the process right. Journal of Managerial Psychology, 14(6), 502-511. https://doi.org/10.1108/02683949910287921

Avery, G. C., \& Bergsteiner, H. (2011). How BMW successfully practices sustainable leadership principles. Strategy \& Leadership, 39(6): 11-18. https://doi.org/10.1108/10878571111176583

Bansal, P., \& Corley, K. (2012). From the Editors: Publishing in AMJ-Part 7: What's different about qualitative research. Academy of Management, 55(3), 509-513. https://doi.org/10.5465/amj.2012.4003

Barrett, F. J., \& Fry, R. E. (2008). Appreciative inquiry: A positive approach to building cooperative capacity. Chagrin Falls: A Taos Institute Publication.

Berkovich, I. (2014). Between person and person: Dialogical pedagogy in authentic leadership development. Academy of Management Learning \& Education, 13(2), 245-264. https://doi.org/10.5465/amle.2012.0367

Berson, Y., Shamir, B., Avolio, B. J., \& Popper, M. (2001). The relationship between vision strength, leadership style, and context. The Leadership Quarterly, 12(1), 53-73. https://doi.org/10.1016/S1048-9843(01)00064-9

Boal, K. B., \& Hooijberg, R. (2000). Strategic leadership research: moving on. The Leadership Quarterly, 11(4), 515-549. https://doi.org/10.1016/S1048-9843(00)00057-6

Boeije, H. (2010). Analysis in qualitative research. Los Angeles: Sage Publications.

Boyce, L. A., Zaccaro, S. J., \& Wisecarver Zazanis, M. (2010). Propensity for self-development of leadership attributes: Understanding, predicting, and supporting performance of leader self-development. The Leadership Quarterly, 21(1), 159-178. https://doi.org/10.1016/j.leaqua.2009.10.012

Branten, E., \& Purju, A. (2015). Cooperation projects between university and companies: process of formation and objectives of the stakeholders. Entrepreneurship and Sustainability Issues, 3(2), 149156. https://doi.org/10.9770/jesi.2015.3.2(3)

Carroll, B., Levy, L., \& Richmond, D. (2008). Leadership as practice: Challenging the competency paradigm. Leadership, 4(1), 363-379. https://doi.org/10.1177/1742715008095186

Chen, I. (2014). For frustrated gifted kids, a world of online opportunities. KQED. Retrieved from http:// ww2.kqed.org/mindshift/2014/05/21/for-frustrated-gifted-kids-a-world-of-online-opportunities/

Clark, R. C. (2012). Blended learning is better than instructor-led or online learning alone. Retrieved from https://www.td.org/Publications/Blogs/L-and-D-Blog/2012/07/Blended-Learning-Is-Better-ThanInstructor-Led-or-Online-Learning-Alone

Collinson, D. (2005). Dialectics of leadership. Human Relations, 58(11), 1419-1442. https://doi.org/10.1177/0018726705060902

Dalati, S., \& Al Hamwi, S. E. (2016). Sustainable development in higher education through service quality and price fairness: empirical evidence from private universities in Syria. Entrepreneurship and Sustainability Issues, 4(1), 25-38. https://doi.org/10.9770/jesi.2016.4.1(3)

Daly, C. (2009). A learning management system ... or an intelligent tutoring system? Learning Solutions Magazine. Retrieved from http://www.learningsolutionsmag.com/articles/45/a-learning-management-system--or-an-intelligent-tutoring-system

DeRue, D. S., \& Ashford, S. (2010). Power to the people. Where has personal agency gone in leadership development?. Industrial and Organizational Psychology, 3(1), 24-27. https://doi.org/10.1111/j.1754-9434.2009.01191.x

DeRue, D. S., \& Wellman, N. (2009). Developing leaders via experience: The role of developmental challenge, learning orientation, and feedback availability. Journal of Applied Psychology, 94(4), 859875. https://doi.org/10.1037/a0015317

Dobrovolskienė, N., Tvaronavičienė, M., \& Tamošiūnienè, R. (2017). Tackling projects on sustainability: A Lithuanian case study. Entrepreneurship and Sustainability Issues, 4(4), 477-488.

https://doi.org/10.9770/jesi.2017.4.4(6) 
DreamBox. (2013). Five benefits of blended learning Written. Retrieved from http://www.dreambox. com/blog/five-benefits-of-blended-learning\#sthash.zxFz1A5I.dpuf

Epstein, M. J., \& Roy, M. J. (2003). Improving sustainability performance: Specifying, implementing and measuring key principles. Journal of General Management, 29(1), 15-31. https://doi.org/10.1177/030630700302900101

Eriksson, P., \& Kovalainen, A. (2008). Qualitative methods in business research. London: SAGE Publications Ltd. https://doi.org/10.4135/9780857028044

European Commission. (2011). Supporting growth and jobs: An Agenda for the modernisation of Europe's Higher Education System. Education and Culture DG. Retrieved from http://ec.europa.eu/education/library/policy/modernisation_en.pdf

European Commission. (2013). Communication from the Commission to the European Parliament, the Council, the European Economic and Social Committee and the Committee of the Regions. European Higher Education in the World. Brussels, 11.7.2013 COM 499 final. Retrieved from http:// ec.europa.eu/transparency/regdoc/rep/1/2013/EN/1-2013-499-EN-F1-1.Pdf

Eurostat. (2015). Tertiary education statistics. Eurostat. Retrieved from http://ec.europa.eu/eurostat/ statistics-explained/index.php/Tertiary_education_statistics

Fuschi, D. L., \& Tvaronavičienè, M. (2016). A network based business partnership model for SMEs management. Entrepreneurship and Sustainability Issues, 3(3), 282-289. https://doi.org/10.9770/jesi.2016.3.3(5)

Grooms, L. D., \& Reid-Martinez, K. (2011). Sustainable leadership development: A conceptual model of a cross-cultural blended learning program. International Journal of Leadership Studies, 6(3), 412429.

Gurr, D. (2007). Developing sustainable leadership. Australian Journal of Education, 51(3), 341-342. https://doi.org/10.1177/000494410705100310

Haque, M., TitiAmayah, A., \& Liu, L. (2016). The role of vision in organizational readiness for change and growth. Leadership \& Organization Development Journal, 37(7), 983-999.

https://doi.org/10.1108/LODJ-01-2015-0003

Hardy, C., \& Tolhurst, D. (2014). Epistemological beliefs and cultural diversity matters in management education and learning: A Critical review and future directions. Academy of Management Learning \& Education, 13(2), 265-289. https://doi.org/10.5465/amle.2012.0063

Hargreaves, A. (2007). Sustainable leadership and development in education: Creating the future, conserving the past. European Journal of Education, 42(2), 223-233.

https://doi.org/10.1111/j.1465-3435.2007.00294.x

Hartman, N. S., Allen, S. J., \& Miguel, R. F. (2015). An exploration of teaching methods used to develop leaders: Leadership educators' perceptions. Leadership \& Organization Development Journal, 36(5), 454-472. https://doi.org/10.1108/LODJ-07-2013-0097

Hernandez, Y., Arroyo-Figueroa, G., \& Sucar, L. E. (2007). Intelligent tutoring system with affective behavior. In $6^{\text {th }}$ Mexican International Conference on Artificial Intelligence, Special Session (MICAI) (pp. 352-362). Aguascallentes, Mexico: IEEE. https://doi.org/10.1109/MICAI.2007.15

Hernandez, Y., Sucar, L.E., \& Arroyo-Figueroa, G. (2008). Building an affective model for intelligent tutoring systems with base on lecturers' expertise. In A. Gelbukh, \& E. F. Morales (Eds.), MICAI 2008: Advances in Artificial Intelligence. Lecture Notes in Computer Science 5317 (pp. 754-764). Springer Berlin Heidelberg. https://doi.org/10.1007/978-3-540-88636-5_71

Hibbert, P. (2012). Approaching reflexivity through reflection: Issues for critical management education. Journal of Management Education, 37(6), 803-827. https://doi.org/10.1177/1052562912467757

Hill, C. W. L., \& Jones, G. R. (2007). Strategic management: An integrated approach. Boston, New York: Houghton Migglin Company. 
Hogo, M. A. (2010). Evaluation of e-learning systems based on fuzzy clustering models and statistical tools. Expert Systems with Applications, 37(10), 6891-6903.

https://doi.org/10.1016/j.eswa.2010.03.032

Holtschlag, C., \& Masuda, A. D. (2011). The impact of career visions on work attitudes: a longitudinal approach. Career Development International, 16(7), 668-683.

https://doi.org/10.1108/13620431111187281

Hunt, C. (2011). National strategy for higher education to 2030 Report. Dublin: Government publications office.

Kaklauskas, A, Zavadskas, E. K., Pruskus, V., Vlasenko, A., Seniut, M., Kaklauskas, G., Matuliauskaite, A., \& Gribniak, V. (2010). Biometric and intelligent self-assessment of student progress system. Computers \& Education, 55(2), 821-833. https://doi.org/10.1016/j.compedu.2010.03.014

Kaklauskas, A., Zavadskas, E. K., Pruskus, V., Vlasenko, A., Bartkiene, L., Paliskiene, R., Zemeckyte, K., Gerstein, V., Dzemyda, G., \& Tamulevicius, G. (2011). Recommended biometric stress management system. Expert Systems with Applications, 38(11), 14011-14025.

https://doi.org/10.1016/j.eswa.2011.04.209

Kaklauskas, A., Zavadskas, E. K., Seniut, M., Stankevic, V., Raistenskis, J., Simkevičius, C., Stankevic, T., Matuliauskaite, A., Bartkiene, L., Zemeckyte, L., Paliskiene, R., Cerkauskiene, R., \& Gribniak, V. (2013). Recommender system to analyze student's academic performance. Expert Systems with Applications, 40(15), 6150-6165. https://doi.org/10.1016/j.eswa.2013.05.034

Kaklauskas, A. (2015). Biometric and intelligent decision making support. Series: Intelligent systems reference library (Vol. 81), Berlin: Springer-Verlag.

Kaklauskas, A., Kuzminske, A., Zavadskas, E. K., Daniunas, A., Kaklauskas, G., Seniut, M., Raistenskis, J., Safonov, A., Kliukas, R., Juozapaitis, A., Radzeviciene, A., \& Cerkauskiene, R. (2015). Affective tutoring system for built environment management. Computers \& Education, 82, 202-216. https://doi.org/10.1016/j.compedu.2014.11.016

Kantabutra, S. (2010). Vision effects: a critical gap in educational leadership research. International Journal of Educational Management, 24(5), 376-390. https://doi.org/10.1108/09513541080000451

Klašnja-Milićević, A., Vesin, B., Ivanović, M., \& Budimac, Z. (2011). E-Learning personalization based on hybrid recommendation strategy and learning style identification. Computers \& Education, 56(3), 885-899. https://doi.org/10.1016/j.compedu.2010.11.001

Levin, I. M. (2000). Vision revisited telling the story of the future. The Journal of Applied Behavioral Science, 36(1), 91-107. https://doi.org/10.1177/0021886300361005

Matetskaya, M. (2015). Education programmes for entrepreneurs in the creative industries in St. Petersburg. Entrepreneurship and Sustainability Issues, 3(1), 66-73. https://doi.org/10.9770/jesi.2015.3.1(6)

McCall, M. W. (2010). Recasting leadership development. Industrial and Organizational Psychology, 3(1), 3-19. https://doi.org/10.1111/j.1754-9434.2009.01189.x

Miles, R. E., Snow, C. C., Meyer, A. D., \& Coleman, H. J. (1978). Organizational strategy, structure, and process. Academy of Management Review, 3(3), 546-562. https://doi.org/10.5465/amr.1978.4305755

Moga, H., Antonya, C., \& Boboc, R.G. (2014). Affective tutoring system based on extended controlvalue emotional agent and 3x5 RLO matrix. Procedia - Social and Behavioral Sciences, 141, 418-423. https://doi.org/10.1016/j.sbspro.2014.05.073

Murphy, S. E., \& Johnson, S. K. (2011). The benefits of a long-lens approach to leader development: Understanding the seeds of leadership. The Leadership Quarterly, 22(3), 459-470. https://doi.org/10.1016/j.leaqua.2011.04.004

Oganisjana, K., \& Surikova, S. (2015). Social innovation in the promotion of sustainable development of the contemporary Latvian society. Journal of Security and Sustainability Issues, 5(2), 249-258. https://doi.org/10.9770/jssi.2015.5.2(10) 
Oganisjana, K., Svirina, A., Surikova, S., Grīnberga-Zālīte, G., \& Kozlovskis, K. (2017). Engaging society and universities for sustainable entrepreneurship. Entrepreneurship and Sustainability Issues, 5(1), 9-22. https://doi.org/10.9770/jesi.2017.5.1(1)

Penger, S. (2006). Učeča se organizacija in oblikovanje pozitivne organizacijske identitete: študija primera slovenskega podjetja/Learning organization and design of positive organizational identity: case study of Slovene company. Faculty of Economics, Ljubljana.

Peterlin, J., Dimovski, V., Uhan, M., \& Penger, S. (2015). Integrating stakeholders' multiple intelligences into the leadership development of a cross-cultural entity: evidence from the CI Ljubljana. Journal for East European Management Studies, 20(2), 202-225. https://doi.org/10.5771/0949-6181-2015-2-202

Petriglieri, G. (2012). Identity workspaces for leadership development. In S. Snook, N. Nohria, \& R. Khurana (Eds.), The handbook for teaching leadership: Knowing, doing, and being. Thousand Oaks, CA: SAGE.

Raudeliūnienė, J., Stadnik, B., \& Kindaryte,, R. (2016). Knowledge appliance process: theoretical and practical evaluation aspects. Entrepreneurship and Sustainability Issues, 3(4), 368-379. https://doi.org/10.9770/jesi.2016.3.4(5)

Testa, M. R. (1999). Satisfaction with organizational vision, job satisfaction and service efforts: An empirical investigation. Leadership \& Organization Development Journal, 20(3), 154-161. https://doi.org/10.1108/01437739910268424

Tvaronavičienè, M., \& Černevičiūtè, J. (2015). Technology transfer phenomenon and its impact on sustainable development. Journal of Security and Sustainability Issues, 5(1), 87-97. https://doi.org/10.9770/jssi.2015.5.1(7)

Ungaretti, T., Thompson, K. R., Miller, A., \& Peterson, T. O. (2015). Problem-based learning: Lessons from medical education and challenges for management education. Academy of Management Learning \& Education, 14(2), 173-186. https://doi.org/10.5465/amle.2013.0245

Volchik, V., \& Maslyukova, E. (2017). Performance and sustainability of higher education: key indicators versus academic values. Journal of Security and Sustainability Issues, 6(3), 501-512. https://doi.org/10.9770/jssi.2017.6.3(14)

Yoeli, R., \& Berkovich, I. (2010). From personal ethos to organizational vision: narratives of visionary educational leaders. Journal of Educational Administration, 48(4), 451-467. https://doi.org/10.1108/09578231011054716

Zemlickienè, V., Mačiulis, A., \& Tvaronavičienè, M. (2017). Factors impacting the commercial potential of technologies: expert approach. Technological and Economic Development of Economy, 23(2), 410427. https://doi.org/10.3846/20294913.2016.1271061 